\title{
Effect of protistan bacterivory on coastal bacterioplankton diversity
}

\author{
Marcelino T. Suzuki* \\ Monterey Bay Aquarium Research Institute, 7700 Sandholdt Road, PO Box 628, Moss Landing, California 95039-0628, USA
}

\begin{abstract}
Four protist exclusion experiments were conducted to test the hypothesis that marine bacterivorous protists selectively feed on different bacterioplankton genotypes and affect the taxonomic diversity of coastal marine bacterioplankton communities. In these experiments, the changes in bacterial community composition of seawater samples from which protists were removed by filtration were followed and compared to those of untreated control water samples. Bacterioplankton community structure was inferred from the relative abundance of bacterial small subunit rRNA genes (SSU rDNAs) by a recently developed technique (length heterogeneity analysis by PCR (LH-PCR; Suzuki et al. 1998). The results of the experiments show that the community structure did not dramatically change up to a $24 \mathrm{~h}$ incubation period in any of the treatments. However there were significant differences in filtered water samples and controls between 24 and $48 \mathrm{~h}$ of incubation. In the absence of bacterivores some SSU rDNAs that were rare in the original water samples dominated the bacterioplankton SSU rDNA pool after $48 \mathrm{~h}$ of incubation. Protists appeared to be capable of controlling bacterioplankton taxonomic diversity under these manipulated conditions. The results also agree with the hypothesis that aquatic

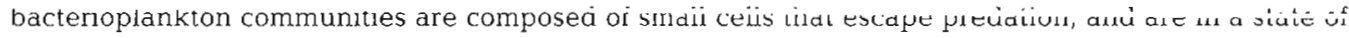
low physiological turnover.
\end{abstract}

KEY WORDS: Bacterivory effects - Bacterioplankton diversity

\section{INTRODUCTION}

The relative importance of different mechanisms controlling bacterioplankton populations is a topic of debate in aquatic ecology. Several studies have attempted to estimate the relative importance of bottom-up versus top-down controls of bacterioplankton community structure, but the question remains unanswered (Shiah \& Ducklow 1995, Dufour \& Torréton 1996). Nonetheless, in the past decade, both theoretical and empirical evidence demonstrate that bacterivorous protists can select their prey based on size (Chrzanowski \& Simek 1990, Gonzalez et al. 1990, Monger \& Landry 1992) or quality (Mitchell et al. 1988, Landry et al. 1991, Gonzalez et al. 1993) and can potentially control the size distribution of aquatic bacterioplankton. Sherr et al. (1992) have shown that bacterivorous protists selectively graze on dividing cells, therefore affecting bacterio-

\footnotetext{
•E-mail: suzuki@mbari.org
}

plankton net production as well as standing stock. Furthermore, recent studies show that different size classes of freshwater bacterioplankton are differentially affected by bacterivory (Pernthaler et al. 1996) and that protist grazing rates are higher on active than on inactive bacterioplankton cells (del Giorgio et al. 1996). These results support the hypothesis that a large fraction of aquatic bacterioplankton is composed of small cells that escape predation, and that are in a state of low physiological turnover (Kjelleberg et al. 1987).

Assuming that bacterioplankton cells from different taxonomic groups represent different states of metabolic turnover, the same hypothesis suggests that bacterivorous protists could affect bacterioplankton genotypic community structure. Recent studies (Pernthaler et al. 1997, Simek et al. 1997, Hahn \& Höfle 1998) examined the effect of bacterivorous protists on the genotypic community composition of mixed assemblages of freshwater bacterioplankton growing in enriched continuous culture. These studies used oligonucleotide hybridization to bacterial small subunit 
(SSU) IRNA to assess community diversity and showed shifts in the community under grazing pressure. In these experiments the bacterial biomass became dominated by grazing-resistant cells belonging to the beta subdivision of Proteobacteria. Pernthaler et al. (1997) also reported that small, fast-growing cells belonging to the alpha subdvision of the Proteobacteria became the numerically dominant bacterioplankton type.

Here, I report indications that bacterivorous protists preferentially fed on bacterioplankton genotypes that were stimulated in bottle incubations of natural seawater samples and thus have the potential to affect the taxonomic diversity of natural bacterioplankton communities. To evaluate the effect of selective bacterivory by protists on marine bacterioplankton genotypic community structure, I followed the changes in the bacterioplankton community structure in 4 protist exclusion experiments. In these experiments the changes in coastal bacterioplankton communities that had protists removed by gentle filtration was compared to the changes in the bacterioplankton community of untreated controls. Bacterioplankton community structure was inferred using length heterogeneity analysis by PCR (LH-PCR), a recently developed PCR-based method that estimates the relative proportions of SSU rDNAs belonging to different bacterioplankton genotypes from their proportions in PCR products (Suzuki et al. 1998).

\section{MATERIAL AND METHODS}

Four protist exclusion experiments were performed using 4 different water samples from the Oregon coast. In these experiments bacteria were separated from bacterivorous protists by size fractionation. The community structure inferred by LH-PCR was followed with time and compared with that of an unfiltered control. Cell counts were performed for all samples, except when otherwise noted. The experiments are referred to hereafter as PROTEX 1 to 4.

Water samples. Water samples were collected at different times and locations off the Oregon coast. The water samples used for PROTEX 1 (March 28, 1993) and PROTEX 4 (July 24, 1997) were collected at subsurface $(10 \mathrm{~m})$ by Niskin (General Oceanics, Miami, FL) bottles (PROTEX 1) or from the surface using a bucket (PROTEX 4), aboard the RV 'Sacajawea' at a station located $8 \mathrm{~km}$ off the mouth of Yaquina Bay, Oregon $\left(44^{\circ} 39.1^{\prime} \mathrm{N}, 124^{\circ} 10.6^{\prime} \mathrm{W}\right)$. The water sample used for PROTEX 2 (October 3, 1993) was collected at subsurface $(10 \mathrm{~m})$ by Niskin bottles aboard the RV 'Wecoma' at a station located off the mouth of the Columbia River, Oregon $\left(47^{\circ} 17.06^{\prime} \mathrm{N}, 124^{\circ} 44.8^{\prime} \mathrm{W}\right)$.
The water sample used for PROTEX 3 (March 25, 1997) was collected from the surface with a bucket at the South Jetty of the Yaquina Bay, Oregon $\left(44^{\circ} 36.8^{\prime} \mathrm{N}\right.$, $\left.124^{\circ} 10.6^{\prime} \mathrm{W}\right)$

PROTEX 1. The water sample was pre-screened through a $10 \mu \mathrm{m}$ mesh. Two $4 \mathrm{l}$ subsamples were filtered through $0.8 \mu \mathrm{m}$ polycarbonate membranes (Poretics, Osmonics, Minnetonka, MN) and used to fill two $4 \mathrm{l}$ polycarbonate bottles. The controls consisted of two $4 \mathrm{l}$ polycarbonate bottles filled with unfiltered water. At time zero and $24 \mathrm{~h}$ after the start of incubation in the dark at $15^{\circ} \mathrm{C}$, the water from one of the treatment bottles and one of the control bottles was filtered through $0.2 \mu \mathrm{m}$ polysulfone filters (Supor-200, Gelman Inc., Ann Arbor, MI). The filters were immersed in sucrose lysis buffer $(40 \mathrm{mM}$ EDTA, $400 \mathrm{mM} \mathrm{NaCl}, 0.75 \mathrm{M}$ sucrose, $50 \mathrm{mM}$ Tris $\mathrm{HCl} \mathrm{pH} 9.0$ ) and stored at $-80^{\circ} \mathrm{C}$ for later analysis.

PROTEX 2. Nine $4 \mathrm{l}$ subsamples were filled with subsample filtered through a $2.0 \mu \mathrm{m}$ polycarbonate membrane. Nine $4 \mathrm{l}$ polycarbonate bottles were filled with unfiltered water and served as controls. At time zero and after 12 and $24 \mathrm{~h}$ incubation at surface temperature in an ondeck Plexiglas incubator the water from 3 of the treatment bottles and 3 of the control bottles was filtered through $0.2 \mu \mathrm{m}$ polysulfone filters and the filters stored as above.

PROTEX 3 and 4 . Seven $500 \mathrm{ml}$ subsamples were filtered once through GF/F glass fiber filters (Whatman, Kent, UK) and twice through $0.8 \mu \mathrm{m}$ polycarbonate membranes. To avoid the effects caused by separation of bacteria from bacterivorous protists and eukaryotic phytoplankton on substrate availability and nutrient feedback to the bacterioplankton, the samples were incubated in $500 \mathrm{ml}$ polysulfone filter holders with receivers (Nalgene, Rochester, NY, Item 300-4050). The unfiltered controls were poured into the bottom collection flask, the filtered subsamples were gently poured in the top filtration tower closed with a lid and the subsamples were separated by a $0.2 \mu \mathrm{m}$ polycarbonate membrane that allowed inorganic nutrients and organic substrates to exchange. At time zero and after 16, 24, 30, 37, 42 and 48 h (PROTEX 3) or 14, 24, $30,34,42$ and 48 h (PROTEX 4) of incubation in the dark at $15^{\circ} \mathrm{C}$ under gentle shaking (the filtration flasks were lying on their sides), the water from one of the treatment bottles and one of the controls was filtered through $0.2 \mu \mathrm{m}$ polysulfone filters and the filters stored as above.

Cell counts. In PROTEX 2, $20 \mathrm{ml}$ samples were collected from all treatment and control subsamples, preserved, stained, and filtered onto 0.2 or $0.8 \mu \mathrm{m}$ polycarbonate filters for enumeration of bacteria and of heterotrophic flagellates via DAPI staining (Sherr et al. 1993, Turley 1993). Bacterivorous protists were not enu- 
merated in the controls of PROTEX 1. In PROTEX 1, 3 and $4,20 \mathrm{ml}$ samples were collected from 1 treatment and 1 control bottle at each time immediately before the remainder of the samples were filtered for nucleic acid samples. The sample for initial bacterial counts for the filtered sample of PROTEX 4 was accidentally lost.

LH-PCR. Total cellular nucleic acids were extracted from the polysulfone filters by lysis with proteinase $\mathrm{K}$ and SDS, followed by phenol/chloroform extraction as previously described (Giovannoni et al. 1990b). $10 \mathrm{ng}$ of purified genomic DNA were used as the template for LH-PCR. Details of the LH-PCR protocol are described elsewhere (Suzuki et al. 1998). Briefly, in a final volume of $100 \mu \mathrm{l}$, reactions contained $0.2 \mathrm{mM}$ of premixed dNTPs (Stratagene, La Jolla, CA), $1.5 \mathrm{mM} \mathrm{MgCl}_{2}$, $5 \%$ acetamide and 2.5 units of Taq DNA polymerase (Promega, Madison, WI). The forward primer, 27F (5'AGA GTT TGA TCM TGG CTC AG-3') (Giovannoni 1991), targeted SSU rDNAs from the domain Bacteria and was $5^{\prime}$-end-labeled with the phosphoramidite dye 6 FAM and purchased from Genset (San Diego, CA). The reverse primer, 355R (5'-GCT GCC TCC CGT AGG AGT-3') (Amann et al. 1990), also targeted SSU rDNAs from the domain Bacteria and was synthesized at the Central Services Laboratory, Center for Gene Research and Biotechnology, Oregon State University. All reactions used the Ampliwax ${ }^{\mathrm{TM}}$ hotstart protocol (Perkin

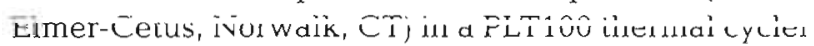
(MJ Research Inc., Watertown, MA) programmed to 16 cycles of $96^{\circ} \mathrm{C}$ denaturation, $1 \mathrm{~min}, 55^{\circ} \mathrm{C}$ annealing, $1 \mathrm{~min}$, and $72^{\circ} \mathrm{C}$ extension, $3 \mathrm{~min}$.
The concentration of labeled PCR products was estimated after electrophoresis in an agarose minigel stained with ethidium bromide $\left(0.5 \mu \mathrm{g} \mathrm{ml} \mathrm{ml}^{-1}\right)$ and comparison with mass standards. The PCR products were purified using Qiaquick-spin columns (Qiagen, Chatsworth, CA) and approximately $10 \mathrm{fmol}$ of the LH-PCR products were discriminated by Long Ranger (FMC, Rockland, ME) polyacrylamide gel electrophoresis in an Applied Biosystems Inc. 377 automated DNA sequencer (Applied Biosystems Inc., Foster City, CA) using the software Genescan ${ }^{\circ}$ (Applied Biosystems Inc.). The software outputs electropherograms in which the bands are represented by peaks and the integrated fluorescence of each band is the area under the peaks. The relative abundance of each amplicon was estimated as the ratio between the integrated fluorescence of each of the peaks and the total integrated fluorescence of all peaks.

\section{RESULTS}

\section{Cell counts}

In all experiments the total numbers of bacteria in the filtered water treatments and in the controls

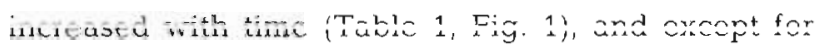
PROTEX 4 (Fig. 1B), there was no decline in bacterial numbers in the control populations. In all experiments using water filtered through $0.8 \mu \mathrm{m}$, the initial num-

Table 1. Time series of bacteria and bacterivorous protists in experimental (filtered) and control (unfiltered) water samples. Cell numbers of PROTEX 2 are averages and standard deviations for tripicate bottles. bd: below detection, ns: no sample

\begin{tabular}{|c|c|c|c|c|c|c|c|c|c|}
\hline \multirow{3}{*}{$\begin{array}{l}\text { Time } \\
\text { (h) } \\
0\end{array}$} & \multicolumn{2}{|c|}{$\begin{array}{c}\text { PROTEX } 1 \\
\text { Bacteria }\left(10^{6} \text { cells } \mathrm{ml}^{-1}\right)\end{array}$} & \multicolumn{7}{|c|}{ Bacteria $\left(10^{6}\right.$ cells $\left.\mathrm{ml}^{-1}\right)$} \\
\hline & \multirow{2}{*}{$\begin{array}{c}<0.8 \mathrm{~m} \\
1.67\end{array}$} & \multirow{2}{*}{$\begin{array}{c}\text { Unfiltered } \\
2.07\end{array}$} & \multirow{2}{*}{$\begin{array}{c}<2.0 \mathrm{~m} \\
2.21+0.15\end{array}$} & \multicolumn{2}{|c|}{ Unfiltered } & \multicolumn{2}{|c|}{$<2.0 \mathrm{~m}$} & \multicolumn{2}{|c|}{ Unfiltered } \\
\hline & & & & 2.14 & 0.12 & 1.51 & 1.33 & 8.42 & 3.79 \\
\hline 12 & & & $2.86 \quad 0.07$ & 2.29 & 0.11 & 0.85 & 0.58 & 10.4 & 2.87 \\
\hline \multirow[t]{4}{*}{24} & 2.90 & 2.37 & $3.34 \quad 0.14$ & 1.65 & 0.20 & 3.37 & 1.54 & 8.59 & 3.64 \\
\hline & \multicolumn{3}{|c|}{ PROTEX 3} & \multicolumn{6}{|c|}{ PROTEX 4} \\
\hline & \multicolumn{2}{|c|}{ Bacteria $\left(10^{6}\right.$ cells $\left.\mathrm{ml}^{-1}\right)$} & \multirow{2}{*}{$\begin{array}{c}\text { Protists } \\
\left(10^{3} \text { cells } \mathrm{ml}^{-1}\right) \\
\text { Unfiltered }\end{array}$} & \multicolumn{4}{|c|}{ Bacteria $\left(10^{6}\right.$ cells $\left.\mathrm{ml}^{-1}\right)$} & \multirow{2}{*}{\multicolumn{2}{|c|}{$\begin{array}{c}\text { Protists } \\
\left(10^{3} \text { cells } \mathrm{ml}^{-1}\right. \\
\text { Unfiltered }\end{array}$}} \\
\hline & $<0.8 \mathrm{~m}$ & Unfiltered & & \multicolumn{2}{|c|}{$<0.8 \mathrm{~m}$} & \multicolumn{2}{|c|}{ Unfiltered } & & \\
\hline 0 & 0.40 & 0.79 & bd & \multicolumn{2}{|c|}{ ns } & \multicolumn{2}{|c|}{1.18} & \multicolumn{2}{|c|}{1.33} \\
\hline 14 & 0.41 & 0.97 & bd & & & & & & \\
\hline 16 & & & & \multicolumn{2}{|c|}{0.09} & \multicolumn{2}{|c|}{3.30} & \multicolumn{2}{|c|}{1.33} \\
\hline 24 & 0.28 & 1.25 & 0.30 & \multicolumn{2}{|c|}{0.12} & \multicolumn{2}{|c|}{3.69} & \multicolumn{2}{|c|}{2.84} \\
\hline 30 & 0.68 & 2.43 & 0.36 & \multicolumn{2}{|c|}{0.23} & \multicolumn{2}{|c|}{3.66} & \multicolumn{2}{|c|}{3.69} \\
\hline 34 & & & & \multicolumn{2}{|c|}{0.35} & \multicolumn{2}{|c|}{2.19} & \multicolumn{2}{|c|}{5.72} \\
\hline 37 & 0.82 & 2.39 & 0.42 & & & & & & \\
\hline 42 & 1.24 & 3.10 & 0.73 & \multicolumn{2}{|c|}{1.53} & \multicolumn{2}{|c|}{2.56} & \multicolumn{2}{|c|}{6.42} \\
\hline 48 & 2.03 & 4.49 & 1.03 & 3. & 01 & 1. & 17 & & 03 \\
\hline
\end{tabular}



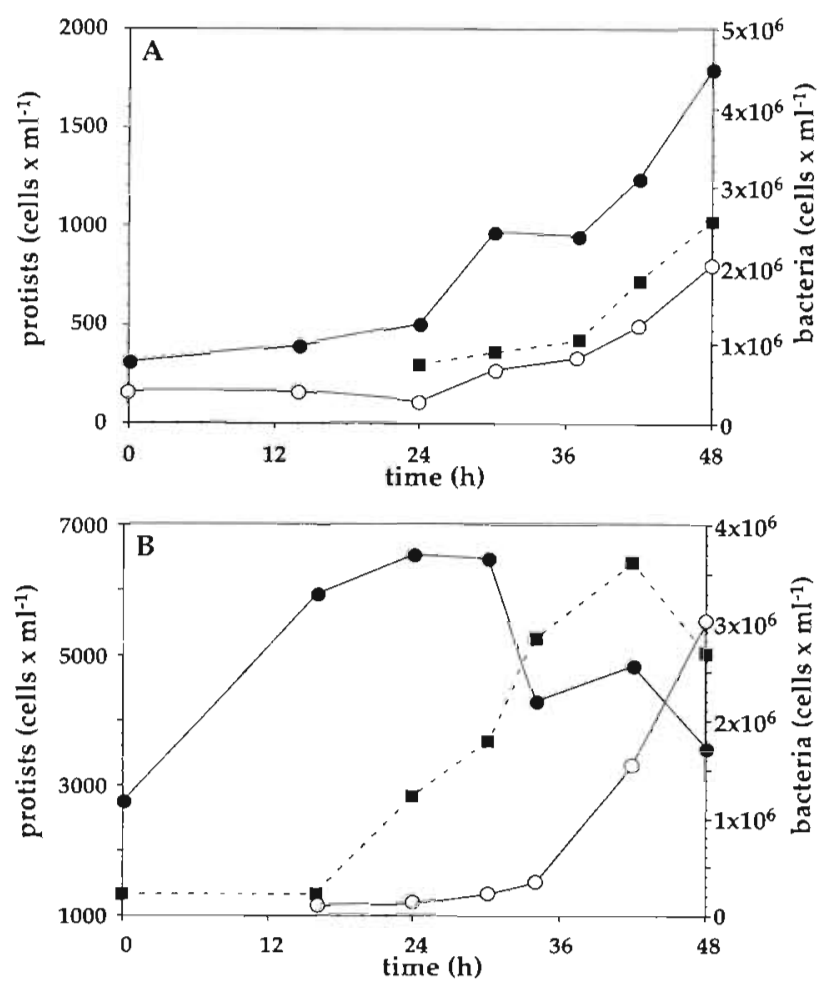

Fig. 1. Time course of bacteria and bacterivorous protists. (A) PROTEX 3. (B) PROTEX 4. (O) Bacteria, $0.8 \mu \mathrm{m}$ filtered water; ( bacteria, controls; ( $\bullet$ bacterivorous protists, controls bers of bacteria in the treatment subsamples were lower and showed a longer lag phase than the controls.

Bacterivorous protist numbers increased with time after a lag phase in the controls of PROTEX 3 and 4 (Fig. 1) and did not grow in the $0.8 \mu \mathrm{m}$ filtered samples. In PROTEX 4 bacterivores apparently controlled the increase in bacterial numbers since the increase in bacterivores was followed by a decrease in the total numbers of bacteria. Bacterivores did not show increasing or decreasing trends in the controls of PROTEX 2 (Table 1), but were present and increased in numbers in the $2.0 \mu \mathrm{m}$ filtered water treatments, with final numbers reaching about $40 \%$ of the numbers in the controls (Table 1).

\section{LH-PCR}

Except for PROTEX 4, the initial community structure was very similar in all the samples (Table 2, Figs. 2A \& 3A). The fragments sized between 315 and 317 base pairs (bp) (Peak 1) were the most abundant fragments in the original samples, representing up to $50 \%$ of the fluorescence of all amplified fragments. An analysis of the sizes of the region between primers $27 \mathrm{~F}$ and 355R of 366 SSU rDNA sequences directly cloned from DNA samples from seawater or belonging to bacteria isolated from seawater showed that these frag-
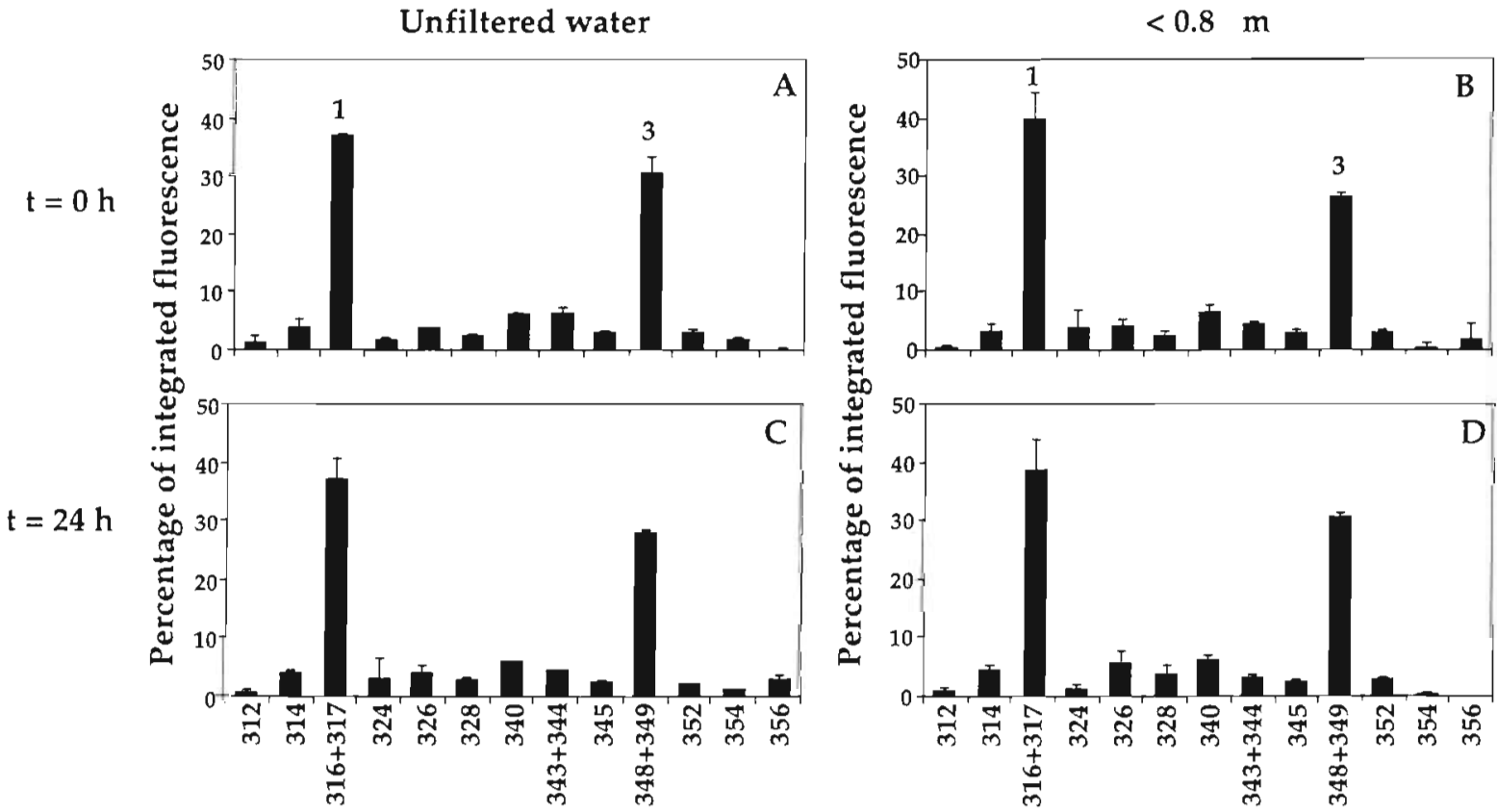

Fig. 2. PROTEX 2. Percentage of integrated fluorescence emission by rRNA of different lengths produced by PCR using primers $27 \mathrm{~F}$ (5'-labeled with 6-FAM) and 355R. The $x$-axis represents the size of domains in base pairs, estimated by comparison to the size standard GS2500 (Applied Biosystems Inc.). Error bars are 1 standard deviation from the average between duplicate (unfiltered water) and triplicate bottles. (A) Control bottles, $t=0 \mathrm{~h}$. (B) Treatment bottles $t=0 \mathrm{~h}$. (C) Control bottles $t=24 \mathrm{~h}$. (D) Treatment bottles, $t=24 \mathrm{~h}$ 
Table 2. Time series of the ratio (\%) of integrated fluorescence of PCR amplified SSU rDNAs of different sizes and the total integrated fluorescence of all PCR amplifed fragments assigned to bacterial SSU rDNAs. Percentages of PROTEX 2 are averages and standard deviation for duplicate (unfiltered water) and triplicate $(<0.2 \mu \mathrm{m})$ bottles

\begin{tabular}{|c|c|c|c|c|c|c|c|c|c|c|c|c|c|c|}
\hline \multirow{2}{*}{$\begin{array}{l}\text { PROTEX } 1 \\
28 \text { March } 1993\end{array}$} & \multirow{2}{*}{$\begin{array}{l}\text { Time } \\
\text { (h) }\end{array}$} & \multirow[b]{2}{*}{312} & \multirow[b]{2}{*}{314} & \multirow[b]{2}{*}{$316+317$} & \multicolumn{4}{|c|}{ Fragment size (bp) } & \multirow[b]{2}{*}{349} & \multirow[b]{2}{*}{$352+353$} & \multirow[b]{2}{*}{354} & \multirow[b]{2}{*}{355} & & \multirow[b]{8}{*}{356} \\
\hline & & & & & 340 & 343 & 346 & 348 & & & & & & \\
\hline \multirow[t]{2}{*}{ Unfiltered } & 0 & 3.1 & 1.7 & 57.6 & 3.7 & 4.8 & 0.0 & 10.1 & 8.9 & 1.7 & 8.4 & 0.0 & & \\
\hline & 24 & 2.2 & 1.9 & 42.7 & 1.9 & 6.3 & 2.0 & 21.1 & 12.8 & 3.4 & 3.0 & 1.1 & & \\
\hline \multirow{2}{*}{$\begin{array}{l}\text { Filtered } \\
(0.8 \mu \mathrm{m})\end{array}$} & 0 & 3.9 & 2.5 & 50.3 & 2.4 & 6.5 & 0.0 & 11.5 & 8.1 & 2.4 & 12.4 & 0.0 & & \\
\hline & 24 & 1.9 & 1.2 & 48.9 & 1.2 & 5.9 & 0.9 & 22.2 & 9.4 & 2.4 & 4.5 & 1.5 & & \\
\hline \multicolumn{6}{|l|}{ PROTEX 2} & \multicolumn{3}{|c|}{ Fragment size (bp) } & & & & & & \\
\hline 3 October 1993 & & 312 & 314 & $316+317$ & 324 & 326 & 328 & 340 & $343+344$ & 345 & $348+349$ & 352 & 354 & \\
\hline \multirow[t]{2}{*}{ Unfiltered } & 0 & $1.3 \pm 1.3$ & $3.8 \pm 1.1$ & $36.8 \pm 0.1$ & $1.5 \pm 0.1$ & $3.8 \pm 0.1$ & $2.6 \pm 0.3$ & $6.1 \pm 0.2$ & $6.1 \pm 1.3$ & $3.0 \pm 0.2$ & $30.6 \pm 2.8$ & $2.8 \pm 0.3$ & $1.5 \pm 0.3$ & $0.2 \pm 0.2$ \\
\hline & 24 & $0.8 \pm 0.2$ & $4.2 \pm 0.5$ & $36.9 \pm 3.8$ & $3.5 \pm 3.1$ & $4.3 \pm 0.9$ & $3.0 \pm 0.1$ & $5.9 \pm 0.1$ & $4.4 \pm 0.1$ & $2.4 \pm 0.3$ & $28.2 \pm 0.4$ & $2.1 \pm 0.1$ & $1.2 \pm 0.0$ & $2.8 \pm 0.9$ \\
\hline \multirow{2}{*}{$\begin{array}{l}\text { Filtered } \\
(0.8 \mu \mathrm{m})\end{array}$} & 0 & $0.5 \pm 0.2$ & $3.5 \pm 0.9$ & $39.7 \pm 4.7$ & $3.7 \pm 3.3$ & $4.3 \pm 1.1$ & $2.6 \pm 0.5$ & $6.4 \pm 1.4$ & $4.4 \pm 0.4$ & $2.9 \pm 0.3$ & $26.6 \pm 0.6$ & $3.0 \pm 0.5$ & $0.6 \pm 0.6$ & $1.8 \pm 2.6$ \\
\hline & 24 & $0.8 \pm 0.4$ & $4.4 \pm 0.9$ & $38.8 \pm 5.3$ & $1.3 \pm 0.6$ & $5.6 \pm 2.3$ & $3.5 \pm 1.3$ & $6.0 \pm 0.7$ & $3.3 \pm 0.3$ & $2.4 \pm 0.2$ & $30.4 \pm 0.9$ & $2.8 \pm 0.3$ & $0.5 \pm 0.2$ & $0.0 \pm 0.0$ \\
\hline \multicolumn{6}{|l|}{ PROTEX 3} & \multicolumn{3}{|c|}{ Fragment size (bp) } & & & & & & \\
\hline 25 March 1997 & & 312 & 314 & $315-317$ & 340 & 341 & $343+344$ & 345 & 348 & $349+350$ & 352 & 354 & 355 & \\
\hline \multirow[t]{7}{*}{ Unfilltered } & 0 & 1.0 & 0.0 & 48.3 & 3.3 & 0.0 & 10.3 & 3.8 & 18.7 & 10.6 & 2.6 & 1.4 & 0.0 & \\
\hline & 14 & 0.5 & 0.0 & 45.4 & 3.7 & 0.0 & 8.6 & 4.6 & 18.3 & 13.7 & 5.2 & 0.0 & 0.0 & \\
\hline & 24 & 0.0 & 0.0 & 30.6 & 2.5 & 0.0 & 2.0 & 4.6 & 30.8 & 16.4 & 13.1 & 0.0 & 0.0 & \\
\hline & 30 & 0.0 & 0.0 & 19.6 & 4.7 & 0.0 & 3.5 & 6.3 & 31.4 & 19.0 & 15.5 & 0.0 & 0.0 & \\
\hline & 37 & 0.0 & 0.0 & 23.5 & 6.4 & 0.0 & 3.8 & 6.5 & 31.2 & 17.2 & 11.3 & 0.0 & 0.0 & \\
\hline & 42 & 0.0 & 0.0 & 21.8 & 7.2 & 0.0 & 4.4 & 6.8 & 34.8 & 15.2 & 9.8 & 0.0 & 0.0 & \\
\hline & 48 & 0.0 & 0.0 & 23.9 & 5.8 & 0.0 & 1.7 & 5.6 & 39.3 & 15.2 & 8.6 & 0.0 & 0.0 & \\
\hline Filtered & 0 & 1.0 & 0.8 & 44.1 & 2.5 & 0.0 & 12.1 & 5.2 & 15.0 & 15.0 & 1.6 & 1.6 & 1.0 & \\
\hline$(0.8 \mu \mathrm{m})$ & 14 & 0.9 & 0.4 & 46.7 & 2.1 & 0.0 & 10.5 & 4.5 & 14.4 & 15.0 & 1.5 & 1.7 & 2.1 & \\
\hline & 24 & 0.5 & 0.3 & 29.7 & 0.8 & 2.3 & 7.0 & 9.1 & 26.0 & 16.6 & 6.3 & 1.3 & 0.0 & \\
\hline & 30 & 0.0 & 0.0 & 11.5 & 0.0 & 4.9 & 4.9 & 13.5 & 35.3 & 19.5 & 10.4 & 0.0 & 0.0 & \\
\hline & 37 & 0.0 & 0.0 & 7.4 & 0.0 & 8.0 & 3.5 & 12.8 & $2 y .4$ & 18.0 & $2 U . S$ & u.v & u.v & \\
\hline & 42 & 0.0 & 0.0 & 2.6 & 0.0 & 23.2 & 2.2 & 2.9 & 19.3 & 12.1 & 37.7 & 0.0 & 0.0 & \\
\hline & 48 & 0.0 & 0.0 & 2.6 & 0.0 & 18.4 & 2.7 & 2.8 & 14.1 & 10.2 & 49.3 & 0.0 & 0.0 & \\
\hline PROTEX 4 & & & & & & Frag & gment size & e (bp) & & & & & & \\
\hline 24 July 1997 & & 312 & 314 & $316+317$ & 340 & 341 & $343+344$ & 346 & 348 & $349+350$ & 352 & 354 & 355 & \\
\hline Unfiltered & 0 & 0.0 & 1.1 & 24.8 & 0.0 & 5.2 & 12.0 & 5.2 & 36.7 & 8.1 & 5.2 & 1.8 & 0.0 & \\
\hline & 16 & 0.0 & 0.6 & 31.0 & 0.0 & 4.4 & 3.9 & 3.5 & 47.8 & 7.1 & 1.7 & 0.0 & 0.0 & \\
\hline & 24 & 0.0 & 0.0 & 25.0 & 0.0 & 4.7 & 5.0 & 4.2 & 49.6 & 7.0 & 4.7 & 0.0 & 0.0 & \\
\hline & 30 & 0.0 & 0.8 & 24.7 & 0.0 & 6.9 & 6.5 & 4.6 & 45.4 & 7.7 & 3.4 & 0.0 & 0.0 & \\
\hline & 34 & 0.0 & 1.3 & 26.5 & 0.0 & 5.0 & 5.2 & 4.6 & 43.7 & 7.2 & 6.6 & 0.0 & 0.0 & \\
\hline & 42 & 0.0 & 0.9 & 26.0 & 0.0 & 7.6 & 4.6 & 3.3 & 45.8 & 9.6 & 2.2 & 0.0 & 0.0 & \\
\hline & 48 & 0.0 & 0.0 & 20.6 & 0.0 & 6.1 & 5.1 & 3.7 & 47.1 & 8.7 & 8.0 & 0.0 & 0.0 & \\
\hline Filtered & 0 & 0.8 & 0.0 & 42.0 & 0.0 & 1.7 & 18.4 & 3.3 & 18.2 & 11.3 & 0.0 & 3.0 & 1.2 & \\
\hline$(0.8 \mu \mathrm{m})$ & 16 & 0.5 & 0.0 & 39.2 & 0.0 & 3.8 & 19.3 & 3.7 & 19.3 & 10.7 & 0.0 & 3.4 & 0.0 & \\
\hline & 24 & 0.4 & 0.0 & 38.5 & 0.0 & 7.9 & 12.9 & 3.1 & 21.1 & 9.8 & 2.9 & 3.4 & 0.0 & \\
\hline & 30 & 0.0 & 0.0 & 7.9 & 0.0 & 33.6 & 8.3 & 0.0 & 25.8 & 7.3 & 14.9 & 0.0 & 2.3 & \\
\hline & 34 & 0.0 & 0.0 & 0.4 & 1.4 & 37.9 & 4.8 & 2.0 & 25.9 & 9.8 & 17.7 & 0.0 & 0.0 & \\
\hline & 42 & 0.0 & 0.0 & 0.7 & 3.5 & 75.4 & 0.0 & 0.0 & 7.9 & 0.0 & 12.6 & 0.0 & 0.0 & \\
\hline & 48 & 0.0 & 0.0 & 0.7 & 1.5 & 62.5 & 0.0 & 0.0 & 12.5 & 0.0 & 22.8 & 0.0 & 0.0 & \\
\hline
\end{tabular}

ment sizes correspond exclusively (except for Prymnesiophyte plastids) to the SSU rDNAs sequences of the alpha subdivision of the Proteobacteria (Suzuki et al. 1998). Furthermore, most of these sequences in the databases represent SSU rDNAs directly cloned from environmental DNA samples (Suzuki et al. 1998). The fact that the relative abundance of fragments sized between 315 and 317 bp did not show a noteworthy decrease after filtration through $0.8 \mu \mathrm{m}$ strongly sug- gests that these fragments were of bacterial origin. Fragments sized 348 and 349 bp (Peak 3) were the second most abundant, representing up to $20 \%$ of the fluorescence of all amplified fragments. The size analysis of SSU rDNAs showed that these fragment sizes are shared by different phylogenetic groups, including the gamma and delta subdivisions of the Proteobacteria, and the Flexibacter-Bacteroides-Cytophaga phylum. Most of the sequences correspond to those of culti- 


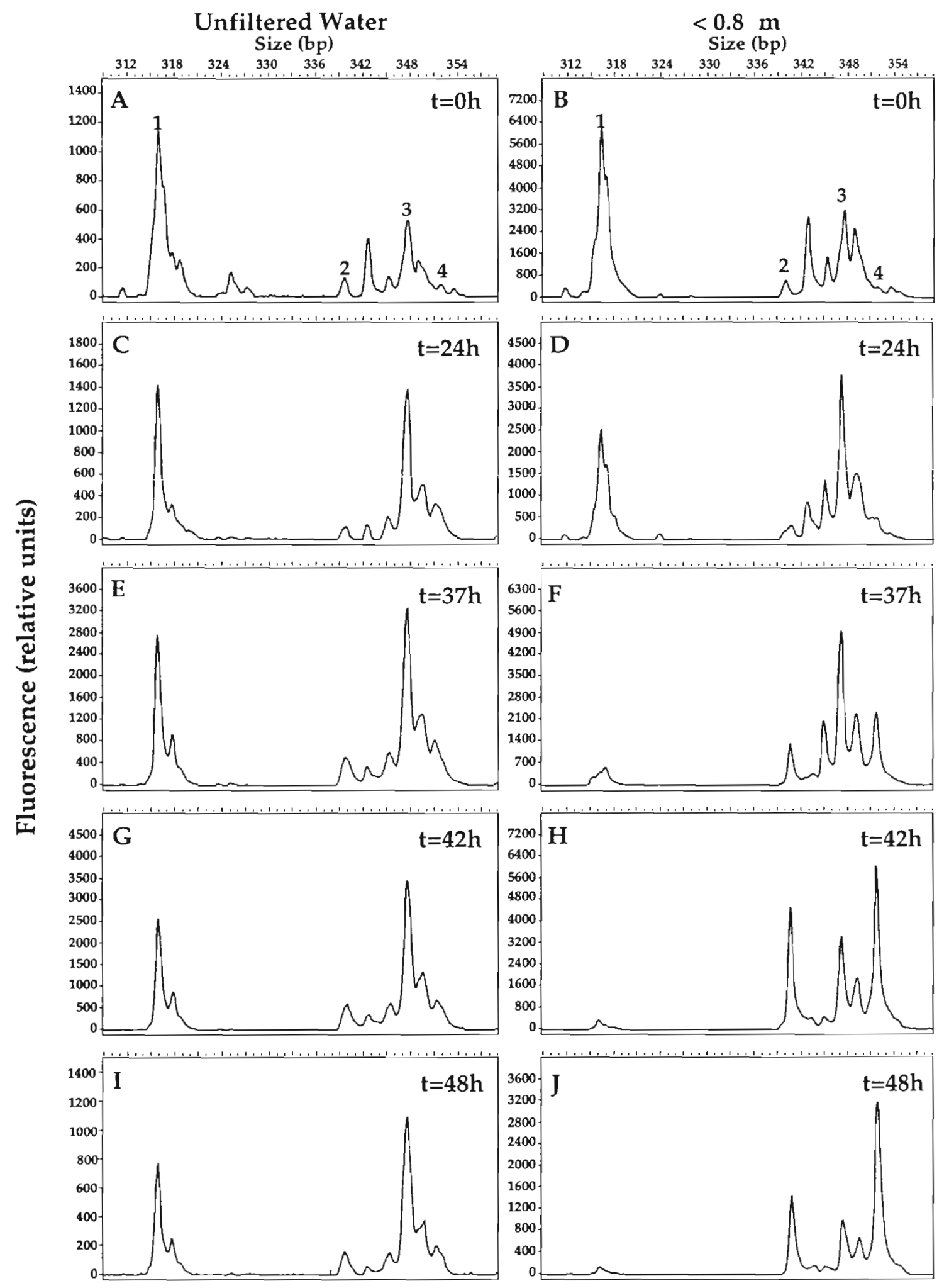

Fig. 3. PROTEX 3.rDNA amplified by PCR using primers 27F (5'-labeled with 6-FAM) and 355R, $x$-axis: size of fragments in base pairs estimated by comparison to the size standard GS2500 (Applied Biosystems Inc.). $y$-axis: relative fluorescence units. (A, C, $E, G, I)$ control bottles; $(B, D, F, H, J)$ treatment bottles 


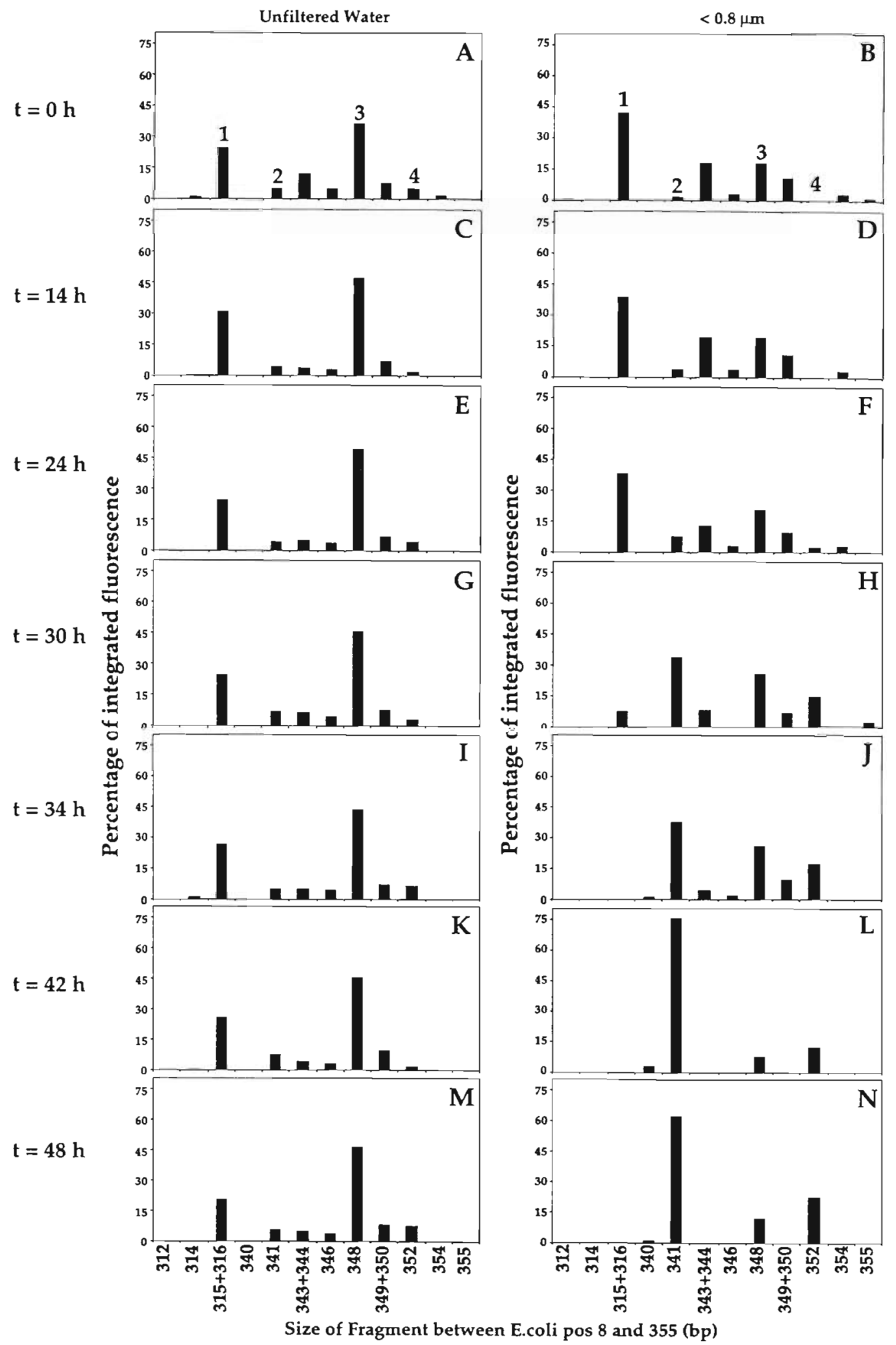

Fig. 4. PROTEX 4. Percentage of integrated fluorescence emission by different sized rDNAs amplified by PCR using primers $27 \mathrm{~F}$ (5'-labeled with 6-FAM) and 355R. X-axis: size of fragments in base pairs estimated by comparison to the size standard GS2500 (Applied Biosystems Inc.). y-axis: relative fluorescence units. (A, C, E, G, I, K, M) control bottles; (B, D, F, H, J, L, N) treatment bottles 
vated organisms (e.g. Flexibacter Iittoralis, Oceanospirillum spp., Shewanella spp., Suzuki et al. 1998).

Filtration through 0.8 or $2.0 \mu \mathrm{m}$ did not dramatically change the community structure of the bacterioplankton inferred by LH-PCR (Table 2, Figs. $2 \mathrm{~A}, \mathrm{~B} \& 3 \mathrm{~A}, \mathrm{~B}$ ) in PROTEX 1 to 3 , even though the initial bacterial counts in the filtered sample of PROTEX 3 was about $50 \%$ of the counts of the controls. This suggests that most bacterioplankton cells were smaller than $0.8 \mu \mathrm{m}$ and/or that a similar fraction of organisms with SSU rRNA contributing to different peaks was smaller than 0.8 $\mu \mathrm{m}$.

The community structure of the water sample used in PROTEX 4, inferred by LH-PCR, was different from that of other water samples (Fig. 4). The fragment sized $348 \mathrm{bp}$ represented the largest fraction of total fluorescence $(\sim 40 \%)$ followed by fragments sized 315 and $316 \mathrm{bp}(\sim 25 \%)$. This difference might be attributed to the samples being collected during a phytoplankton bloom (pers. obs.). Furthermore, filtration through $0.8 \mu \mathrm{m}$ changed the initial community structure, with an increase of the relative proportion of Peak 1, and a decrease in the proportion of Peak 3. This observation suggests that the bacteria contributing to the Peak 3 in PROTEX 4 were either larger and/or particle-associated. Also, although initial numbers of bacteria were not estimated for the unfiltered sample, the bacterial numbers of the $16 \mathrm{~h}$ sample indicate that there was a large difference in initial numbers between filtered and unfiltered samples.

The time courses of community structure showed certain patterns common to almost all of the experiments (Table 2, Figs. 2 to 4). (1) Except for PROTEX 2, the relative fluorescence of Peak 1 decreased with time in all filtered samples as well as in all the controls, while the relative fluorescence of Peak 3 increased with time. (2) After the first $24 \mathrm{~h}$ of incubation the community structure did not change in the filtered water treatments or controls to the same extent as the changes in community structure in treatments and controls incubated for $48 \mathrm{~h}$. (3) After the first $24 \mathrm{~h}$ of incubation in PROTEX 1 to 3 there was no prominent difference between the changes in community structure in the filtered treatments and in controls.

Between 24 and $48 \mathrm{~h}$ of incubation (Table 2, Figs. 3E to I \& $4 \mathrm{G}$ to $\mathrm{N}$ ) there were remarkable differences in the patterns of change in genotypic community structure between filtered samples and unfiltered controls in PROTEX 3 and 4, suggesting that protists were selectively grazing specific bacterial genotypes. In both experiments, the community structure of the $0.8 \mu \mathrm{m}$ filtered samples showed major shifts in the proportions of peaks between 24 and $48 \mathrm{~h}$, while these changes were less pronounced in the controls. In PROTEX 3 , the relative fluorescence of Peak 1 decreased several fold, while Peak 3, followed by several other peaks, dominated the population (Fig. 3F to J). After $42 \mathrm{~h}$ of incubation fragments sized 341 bp (Peak 2) and $352 \mathrm{bp}$ (Peak 4) increased to about 25 and $40 \%$ of the total fluorescence of the $0.8 \mu \mathrm{m}$ filtered samples, and after 48 h incubation, Peak 4 represented about $50 \%$ of the total fluorescence. The decrease in dominance of Peak 1 was less pronounced as it represented about $20 \%$ of the total fluorescence after $48 \mathrm{~h}$ in the controls. In the $0.8 \mu \mathrm{m}$ filtered samples of PROTEX 4 , Peak 2 represented about $30 \%$ of the total fluorescence after $30 \mathrm{~h}$, and after $48 \mathrm{~h}$ became the sole dominant peak ( $65 \%$ of the total fluorescence). In contrast, only a slight decrease in the percentage of fluorescence of Peak 1 was observed after $48 \mathrm{~h}$ of incubation of control samples.

The size analysis of the SSU rDNAs indicates that a fragment of $341 \mathrm{bp}$ could represent different phylogenetic groups, including the beta and gamma subdivisions of the Proteobacteria, and the FlexibacterBacteroides-Cytophaga phylum, most of which are cultivated species (e.g. Pseudoalteromonas spp., Flavobacterium spp.) (Suzuki et al. 1998). The fragment of $352 \mathrm{bp}$ represents marine strains and gene clones of the gamma (environmental clone SAR145, Shewanella hanedaI) and beta (Nitrococcus mobilis) subdivisions of the Proteobacteria (Suzuki et al. 1998).

\section{DISCUSSION}

Selective feeding by aquatic bacterivorous protists has been shown empirically, (Chrzanowski \& Simek 1990, Gonzalez et al. 1990, 1993, Landry et al. 1991. Monger \& Landry 1992, Sherr et al. 1992, del Giorgio et al. 1996, Pernthaler et al. 1996) and has been corroborated by physical models (Monger \& Landry 1990. 1991. Gonzalez. 1996). Earlier studies showed that bacterivores selectively grazed on larger bacterial analogs (Chrzanowski \& Šimek 1990, Gonzalez et al. 1990). Later studies showed also preferential grazing rates on live bacterial cells rather than on heat-killed bacteria. However, the fact that this preferential feeding was only significant for motile bacteria (Monger \& Landry 1992, Gonzalez et al. 1993) led to the suggestion that protistan selective feeding is a function of encounter rates between bacterivores and bacteria, and not a behavioral response by the protists.

Recent studies reinforced the importance of protists' selective feeding to the dynamics of microbial food webs. Observations that protists selectively feed on dividing bacterial cells, led to the hypothesis that protists not only crop bacterial standing stock, but more importantly, selectively feed on the bacterioplankton responsible for secondary production (Sherr et al. 
1992). This hypothesis was supported by results of a study analyzing bacterioplankton size structure in a freshwater lake (Pernthaler et al. 1996). This study showed that bacterivores affected the most active bacterial size class, while abundant, small sized and relatively inactive bacteria were weakly affected by protistan bacterivory (Pernthaler et al, 1996). Finally, the recent report of selective bacterivory on active cells (i.e. capable of reducing the tetrazolium salt CTC; del Giorgio et al. 1996) further supports the hypothesis that bacterivorous protists not only affect bacterioplankton standing stock, but also bacterioplankton net production.

Analysis of replicated bottles for PROTEX 2 showed that the community structure inferred by LH-PCR was consistent between bottles, with a coefficient of variation in general lower than $20 \%$ for most peaks, and patterns of dominance conserved between bottles. Furthermore, the consistency between sequential samples collected in sequential time in PROTEX 3 and 4 strongly suggests that these patterns were a result of changes in the community structure inferred by LHPCR, rather than random experimental error or PCR bias. As in the original description of the method, LHPCR analysis did not consistently discriminate peaks of adjacent fragments, and therefore, the fluorescence of some adjacent fragments were combined (i.e. frag-

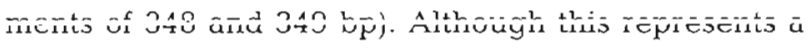
complicating factor in the interpretation of the results, peaks of fragments with similar sizes, in general, represent the same phylogenetic groups (Suzuki et al. 1998).

The results of PROTEX 3 and PROTEX 4 suggest that protists preferentially fed on the fraction of the bacterioplankton growing in the experimental bottles. In both experiments, the structure of the bacterioplankton community changed with time and proportion of the community representing the larger fraction of SSU rDNAs in the original water samples decreased in treatments where protists were absent, as well as in the controls. The percentage of SSU rDNAs of bacteria composing Peaks 2, 3 and 4 dramatically increased while the percentage of SSU rDNAs of bacteria representing the dominant peak in the original samples (Peak 1) decreased after $48 \mathrm{~h}$. In contrast, in controls with protists the percentage of SSU rDNAs corresponding to Peaks 2, 3, and 4 increased to a lesser extent.

The most parsimonious explanation for the increase in proportions of Peaks 2, 3 and 4 in the absence of protists is that the bacteria contributing to those peaks had higher growth rates than those contributing to Peak 1. Regardless of the differences in operon copy numbers between different organisms, if the growth rates had been the same, the proportions between the peaks would not have changed. Higher growth rates of bacteria representing Peaks 2, 3 and 4, combined with preferential bacterivory by protists, could also explain the smaller increase in the proportion of these peaks in the controls

The fact that the initial bacterial counts were lower in filtered samples than in the controls of PROTEX 3 and 4 represents a complicating factor to the interpretation of the results. It is possible that the filtration step could have considerably modified the genotypic diversity and affected the distribution of size, biomass and activity between different members of the community. There is little evidence that the bacteria contributing to Peaks 2, 3 and 4 were larger than those contributing to Peak 1, in the original water samples, since except for PROTEX 4, the relative proportion between the peaks in $0.8 \mu \mathrm{m}$ filtered samples at time zero was similar to that of the unfiltered samples. Also, the fact that the most pronounced change in community structure in PROTEX 3-namely, the decrease in proportion of Peak 1 - was the same in filtered samples and unfiltered controls suggests that filtration alone could not explain the results of PROTEX 3. However, filtration definitely had an effect in PROTEX 4, since the community structure at time zero was different between filtered samples and controls.

Higher mortality rates of bacteria representing Peak 1 in the absence of protists could be also invoked to explain the results. Viral lysis is such an alternative source

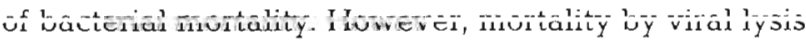
was likely lowered in the filtered samples since encounter rates between viral particles and their hosts was decreased by the lower numbers of bacteria. Furthermore, Peak 1 in LH-PCR represents genes belonging to the alpha subdivision of the Proteobacteria. In most marine samples studied to date this subdivision is represented by organisms belonging to several groups (Suzuki \& DeLong in press). Therefore it is very unlikely that bacteria representing Peak 1 should be entirely and uniquely affected by bacteriophage infection and lysis.

Alternatively, if the community was affected by viral lysis in the original water sample, the decrease in encounter rates between bacteriophages and bacteria could have released some bacteria from this mortality source in filtered water samples, especially in PROTEX 4. However, the observations that the peak that became dominant in PROTEX 4 (Peak 2) represented a small fraction of the peaks in the original population, as well as that this peak continuously dominated the population from 30 to $48 \mathrm{~h}$, does not support the release from viral mortality as a likely explanation to the differences in the changes in community structure between filtered and unfiltered samples.

Another explanation to the results could be lower availability of substrates (from decaying phytoplankton) and inorganic nutrients (regenerated by the protists) in the $0.8 \mu \mathrm{m}$ filtered treatments, and the possibil- 
ity that organisms contributing to Peaks 2, 3 and 4 are better adapted to conditions of substrate and nutrient limitation. However, it is likely that some cell breakage and release of nutrients and substrates occurred during filtration. Added to this, the fact that there was a certain degree of exchange of nutrients and substrates between the chambers precludes the assumption that there were major differences in nutrient and substrate loads between the chambers. The fact that the maximum net growth rates of bacteria in filtered samples in PROTEX 3 and 4 were higher than the maximum net growth rates in the controls - observed before the increase in protist numbers-does not indicate nutrient or substrate limitation in filtered samples, at least early in the incubations. However, the observations that net community growth rates in filtered samples decreased towards the end of the incubations, as well as that the integrated growth rates between 0 and $48 \mathrm{~h}$ in PROTEX 3 were similar between filtered and unfiltered samples, indicate that substrate or nutrient limitation may contribute to the changes observed after $36 \mathrm{~h}$ in PROTEX 3 and after $42 \mathrm{~h}$ in PROTEX 4.

Finally, the long lag times before growth in $0.8 \mu \mathrm{m}$ filtered samples suggest that the bacteria contributing to Peaks 2, 3 and 4 were not active in the original water sample and were stimulated by sample manipulation. Ferguson et al. (1984) showed that the number of bacteria capable of forming colonies in enriched agar plates increased after sample confinement and manipulation. The fact that most SSU rRNA sequences of bacteria cultivated or cloned from seawater, and with sizes corresponding to Peaks 2, 3 and 4 in sequence databases, are indeed those of previously cultivated bacteria agrees with the suggestion that colony-forming bacteria are stimulated by manipulation.

Although the results showed that bacterivorous protists have the potential to preferentially graze on bacteria stimulated in manipulation experiments, it is not possible to directly extrapolate the results to in situ microbial communities. Analysis of the contents of protists' food vacuoles could be an alternative way to examine preferential feeding by bacterivores. Two recent studies have succeeded in hybridizing fluorescent oligonucleotides to cultivated bacteria inside bacterivorous protists' food vacuoles (Gunderson \& Goss 1997. Pernthaler et al. 1997). However, the possibility that most in situ bacterioplankton communities are slow-growing cells that may not have enough ribosomes to allow detection presents a problem to the use of oligonucleotide hybridization to bacteria inside food vacuoles to estimate preferential grazing by protists.

The combined observations that: (1) all known SSU rRNA sequences of bacteria cultivated or cloned from seawater and with the sizes of Peak 1 in sequence databases represent sequences of alpha Proteobacteria;
(2) Peak 1 was dominant in most of the original samples; (3) this peak represented organisms that were outgrown in seawater culture with no protists; and (4) the organisms representing this peak were apparently grazed to a lesser extent than other bacteria support the hypothesis that a large fraction of aquatic bacterioplankton is composed of small cells that escape predation, representing a state of low physiological turnover (Kjelleberg et al. 1987). This hypothesis also helps to explain the discrepancy between the sequences of SSU rDNA of bacterioplankton directly cloned from seawater to those of marine bacterioplankton obtained by cultivation methods (Giovannoni et al. 1990a, Schmidt et al. 1991, DeLong et ai. 1993, Fuhrman et al. 1993, Suzuki et al. 1997), as well as recent observations that a large proportion of natural bacterioplanklon communities are relatively inactive (del Giorgio \& Scarborough 1995, Gasol et al. 1995, del Giorgio et al. 1997). The same observations above seem at tirst to contradict those by Pernthaler et al. (1997), since grazing on smaller alpha Proteobacteria did not appear to be lower than on other bacterial types in their continuous culture experiment. However, in that study the community shifted in the first $24 \mathrm{~h}$ of incubation from being dominated by larger (J. Pernthaler pers. comm.) beta Proteobacteria in the absence of flagellates to being dominated by smaller alpha Proteobacteria in the presence of flagellates, in agreement with the observations presented here. Differences between freshwater and marine bacterial assemblages, as well as the fact that the Pernthaler et al. (1997) assumed that grazing was density-dependent, might also explain the discrepancy between the results of the study of Pernthaler et al. and those presented here.

Since the results of the present study might be the result of bottle effects rather than reflect the dynamics of bacterioplankton populations in situ, the controversy regarding the phylogenetic diversity of active and inactive fractions of bacterioplankton populations (Rehnstam et al. 1993, Pinhassi et al. 1997, Suzuki et al. 1997 ) is far from resolved.

Acknowledgements. I would like to thank my PhD advisors Barry and Evelyn Sherr for their help in the conception of the exclusion experiments, editorial advice and financial support. I am grateful to my $\mathrm{PhD}$ co-advisor Stephen Giovannoni for suggesting the use of LH-PCR of the experiments, editorial advice, financial support and for letting me conduct the experimental work in his laboratory. I would also like to thank Dr Jakob Pernthaler for his comments on my results and willingness to discuss results of his previous studies. and Dr Grieg Steward for comments and editorial advice. This work was supported by National Science Foundation grant OCE 9016373 and Department of Energy grant FG0693ER61697. I was supported by NASA graduate student fellowship for global research no. 4192-GC93-0217. 


\section{LITERATURE CITED}

Amann RI, Binder BJ, Olson RJ, Chisholm SW, Devereux R, Stahl DA (1990) Combination of 165 rRNA-targeted oligonucleotide probes with flow cytometry for analyzing mixed microbial populations. Appl Environ Microbiol 56: 1919-1925

Chrzanowski TH, Šmek K (1990) Prey-size selection by freshwater flagellated protozoa. Limnol Oceanogr 35: $1429-1436$

del Giorgio PA, Scarborough G (1995) Increase in the proportion of metabolically active bacteria along gradients of enrichment in freshwater and marine plankton: implications for estimates of bacterial growth and production rates. J Plankton Res 17:1905-1924

del Giorgio PA, Gasol JM, Vaqué D, Mura P, Agusti S, Duarte CM (1996) Bacterioplankton community structure-protists control net production and the proportion of active bacteria in a coastal marine community. Limnol Oceanogr 41:1169-1179

del Giorgio PA, Prairie YT, Bird DF (1997) Coupling between rates of bacterial production and the abundance of metabolic active bacteria in lakes, enumerated using CTC reduction and flow cytometry. Microb Ecol 34:144-154

DeLong EF, Franks DG, Alldredge AL (1993) Phylogenetic diversity of aggregate-attached vs. free-living marine bacterial assemblages. Limnol Oceanogr 38:924-934

Dufour PH, Torréton JP (1996) Bottom-up and top down control of bacterioplankton from eutrophic to oligotrophic sites in the tropical Northeastern Atlantic Ocean. DeepSea Res 43:1305-1320

Ferguson RL, Buckley EN, Palumbo AV (1984) Response of marine bacterioplankton to differential filtration and con-

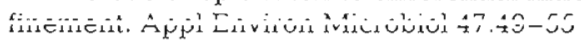

Fuhrman JA, McCallum K, Davis AA (1993) Phylogenetic diversity of subsurface marine microbial communities from the Atlantic and Pacific oceans. Appl Environ Microbiol 59:1294-1302

Gasol JM, del Giorgio PA, Massana R, Duarte CM (1995) Active versus inactive bacteria: size-dependence in a coastal marine plankton community. Mar Ecol Prog Ser 1.23:91-97

Giovannoni SJ (1991) The polymerase chain reaction. In: Stackebrandt E, Goodfellow M (eds) Nucleic acid techniques in bacterial systematics. John Wiley \& Sons, New York, p 177-201

Giovannoni SJ, Britschgi TB, Moyer CL, Field KG (1990a) Genetic diversity in Sargasso Sea bacterioplankton. Nature 345:60-63

Giovannoni SJ, DeLong EF, Schmidt TM, Pace NR (1990b) Tangential flow filtration and preliminary phylogenetic analysis of marine picoplankton. Appl Environ Microbiol 56:2572-2575

Gonzalez JM (1996) Effective size-selective bacterivory by phagotrophic nanoflagellates in aquatic systems. Mar Biol 126:785-789

Gonzalez JM, Sherr EB, Sherr BF (1990) Size-selective grazing on bacteria by natural assemblages of estuarine flagellates and ciliates. Appl Environ Microbiol 56:583-589

Gonzalez JM, Sherr EB, Sherr BF (1993) Differential feeding by marine flagellates on growing versus starving, and on motile versus nonmotile, bacterial prey. Mar Ecol Prog Ser 102:257-267

Gunderson JH, Goss SH (1997) Fluorescently-labeled oligonucleotide probes can be used to identify protistan food vacuole contents. J Eukaryot Microbiol 44:300-304

Hahn MW, Höfle MG (1998) Grazing pressure by a bacterivo- rous flagellate reverses the relative abundance of Comamonas acidovorans PX54 and Vibrio Strain CB5 in chemostat cocultures. Appl Environ Microbiol 64:1910-1918

Kjelleberg S, Hermansson M, Mårdén P, Jones GW (1987) The transient phase between growth and non growth of heterotrophic bacteria, with emphasis on the marine environment. Annu Rev Microbiol 41:25-49

Landry MR, Lehner-Fournier JM, Sundstrom JA, Fagerness VL, Selph KE (1991) Discrimination between living and heat-killed prey by a marine zooflagellate, Paraphysomonas vestita (Stokes). J Exp Mar Biol Ecol 146:139-151

Mitchell GC, Baker JH, Sleigh MA (1988) Feeding of a freshwater flagellate Bodo saltans, on diverse bacteria. J Protozool 35:219-222

Monger BC, Landry MR (1990) Direct-interception feeding by marine zooflagellates: the importance of surface of surface and hydrodynamic forces. Mar Ecol Prog Ser 65: 123-140

Monger BC, Landry MR (1991) Prey-size dependency of grazing by free-living marine flagellates. Mar Ecol Prog Ser 74: 239-248

Monger BC, Landry MR (1992) Size-selective grazing by heterotrophic nanoflagellates: an analysis using livestained bacteria and dual-beam flow cytometry. Arch Hydrobiol Bein Ergebn Limnol 37:173-185

Pernthaler J, Sattler B, Simek K, Schwarzenbacher A, Psenner $\mathrm{R}$ (1996) Top-down effects on the size-biomass distribution of a freshwater bacterioplankton community. Aquat Microb Ecol 10:255-263

Pernthaler J, Posch T, Šimek K, Vrba J, Amann R, Psenner R (1997) Contrasting bacterial strategies to coexist with a flagellate predator in an experimental microbial assemblage. Appl Environ Microbiol 63:596-601

Pinhassi J, Zweifel U, Hagström § (1997) Dominant marine

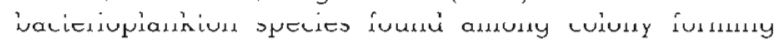
bacteria. Appl Environ Microbiol 63:3359-3366

Rehnstam AS, Backman S, Smith D, Azam F, Hagström A (1993) Blooms of sequence-specific culturable bacteria in the sea. FEMS Microbiol Ecol 102:161-166

Schmidt TM, DeLong EF, Pace NR (1991) Analysis of a marine picoplankton community by $16 \mathrm{~S}$ rRNA gene cloning and sequencing. J Bacteriol 173:4371-4378

Sherr BF, Sherr EB, McDaniel J (1992) Effect of protis tan grazing on the frequency of dividing cells in bacterioplankton assemblages. Appl Environ Microbiol 58: 2381-2385

Sherr EB, Caron DA, Sherr BF (1993) Staining of heterotrophic protists for visualization via epifluorescence microscopy. In: Kemp PF, Sherr BF, Sherr EB, Cole JJ (eds) Handbook of methods in aquatic microbial ecology. Lewis Publ, Boca Raton, p 695-701

Shiah FK, Ducklow HW (1995) Regulation of bacterial abundance and production by substrate supply and bacterivory: a mesocosm study. Microb Ecol 30:239-255

Simek K, Vrba J, Pernthaler J, Posch T, Hartman P, Nedoma J, Psenner R (1997) Morphological and compositional shifts in an experimental bacterial community influenced by protists with contrasting feeding modes. Appl Environ Microbiol 63:587-595

Suzuki MT, Rappé MS, Haimberger ZW, Winfield H, Adair N, Ströbel J, Giovannoni SJ (1997) Bacterial diversity among small-subunit rRNA gene clones and cellular isolates from the same seawater sample. Appl Environ Microbiol 63: 983-989

Suzuki M, Rappe MS, Giovannoni SJ (1998) Kinetic bias in estimates of coastal picoplankton community structure obtained by measurements of small-subunit rRNA gene PCR amplicon length heterogeneity. Appl Environ Microbiol $64: 4522-4529$ 
$64: 4522-4529$

Suzuki $M$, DeLong $E$ (in press) Marine prokaryote diversity. In: Staley J, Reysenbach A (eds) Biodiversity of microbial life: foundation of earth's biosphere. John Wiley \& Sons, New York

Editorial responsibility: John Dolan, Edgewater, Maryland, USA
Turley CM (1993) Direct estimates of bacterial numbers in seawater samples without incurring cell loss during cell storage. In: Kemp PF, Sherr BF, Sherr EB, Cole JJ (eds) Handbook of methods in aquatic microbial ecology. Lewis Publ, Boca Raton, p 143-147

Submitted: February 15, 1999; Accepted: July 3, 1999 Proofs received from author(s): December 20, 1999 